Bond University

Research Repository

\title{
Creating strategy by design
}

Carlopio, James R.

Published in:

Design Principles and Practices

Licence:

Other

Link to output in Bond University research repository.

Recommended citation(APA):

Carlopio, J. R. (2009). Creating strategy by design. Design Principles and Practices, 3(5), 155-166. [1833-1874]. http://ijg.cgpublisher.com/product/pub.154/prod.269

\section{General rights}

Copyright and moral rights for the publications made accessible in the public portal are retained by the authors and/or other copyright owners and it is a condition of accessing publications that users recognise and abide by the legal requirements associated with these rights.

For more information, or if you believe that this document breaches copyright, please contact the Bond University research repository coordinator. 


\section{Bond University}

\section{ePublications@bond}

$1-1-2009$

\section{Creating strategy by design}

James Carlopio

Bond University, James_Carlopio@bond.edu.au

Follow this and additional works at: http://epublications.bond.edu.au/business_pubs

Part of the Organizational Behavior and Theory Commons

\section{Recommended Citation}

James Carlopio. (2009) "Creating strategy by design" Design principles and practices: An international journal, 3 (5), 155-166.

http://epublications.bond.edu.au/business_pubs/185 


\section{Creating strategy by design \\ James Carlopio}

(2009, Design principles and practices: An international journal, 3(5), 155-166)

Design Principles and Practices: An International Journal

The only way to grow sustainably and be successful in the long term is to be remarkable (Godin, 2001, 2005; Porter, 1980, 1996). Being “good enough" is no longer "good enough" because everything is now "good enough" so only the remarkable stands out. The billion-dollar strategic question is, of course, "How do we 'be remarkable"”? Unfortunately, although millions of words and thousands of books and articles have been written on organizational strategy, there is little that can be used to help us actually create strategy. In fact, Hamel (1998, p. 3) said, "Anyone who claims to be a strategist should be intensely embarrassed by the fact that the strategy industry doesn't have a theory of strategy creation! It does not know where bold, new value-creating strategies come from. There is no gaping hole in the middle of the strategy discipline. No, there's no foundation to the strategy discipline! What we need is a deep theory of strategy creation." As hard as it is to believe, Hamel is right. The strategy industry still has no widely accepted theory, methods or tools for strategy creation.

The literature on organizational strategy has been divided into ten distinct schools of thought (Mintzberg, Ahlstrand, \& Lampel, 1998; Mintzberg \& Lampel, 1999). One of the schools is referred to as the design school. One might expect that people who adhere to this design school actually would discuss the process of designing or creating strategy. However, in the design school the term "design" is used in its noun form, in the sense of a form or a structure, rather than in its verb form, in the sense of generating or creating strategy. Adherents to this design school of thought suggest an organization's design (or structural characteristics such as its size or whether it should be functionally or divisionally organised) must be a good fit with, or aligned to, critical elements in its external environment to ensure high performance (cf. Deluzio \& Hawkey, 2006; Mintzberg, 1990; Donaldson, 1985, 2001). When proponents of the design school of thought use the term "design" in its verb form, it is done so only in the sense that an organization's structure must be "tailored to the individual case" or designed to gain "the essential fit between internal strengths and weaknesses and external threats and opportunities” (cf. Mintzberg, 1990, p. 178; Mintzberg \& Lampel, 1999, p. 21). We get no theory of strategy creation from this so called design school.

The most well known school of strategic thought is the positioning school popularised by Porter (1980). In this view, generating strategy is conceived as an analytical process of assessing the external environment (e.g., via Porter's five competitive forces) and discovering which of the three generic strategic positions (i.e., overall cost leadership, differentiation, or focus), or their variants or combinations, is likely to "... yield a superior return on investment for the firm" (Porter, 1980, p. 34). In the planning school, strategy is formally planned; in the entrepreneurial school, strategy is metaphorically envisioned; in the cognitive school, strategy is constructed in peoples' minds, but minimal progress has been made toward clarifying exactly how this is actually done ${ }^{1}$; in the learning school, strategy emerges based on incremental trials and experiments ${ }^{2}$; in the power school, strategy is negotiated, or power and persuasion are used to influence which strategies are chosen, but little is said about how options are generated in the first place; in the cultural school, strategy is formulated via an indistinct collective social process rooted in organizational culture; in the environmental school, strategy is a reaction to the contingencies in its external environment; and

\footnotetext{
${ }^{1}$ This is the school within which our view of strategy design (i.e., strategy generation) most neatly fits, and we are attempting to progress the discussion of exactly how "bold, new value-creating strategies" can be generated.

${ }^{2}$ There are also many elements in the Strategy by Design process that are akin to many of the tenants of the emergent, learning view of strategy.
} 
finally, in the configuration school, proponents are concerned less with strategy per se, than with how an organization transforms its self and changes states when strategy changes (Mintzberg \& Lampel, 1999). None of these schools of strategic thought provides a theory of strategy creation nor any coherent methods and tools for strategy development or creation.

Hambrick and Fredrickson (2005) are among the few in the strategy field who have even used the term "strategy design". However, they argue that "strategy design" is the answer to the following five questions: Where will we be active (arenas)? How will we get there (vehicles)? How will we win in the marketplace (differentiators)? What will be our speed and sequence of moves (strategies)? How will we obtain our returns (economic logic)? They do not tell us how to develop or create strategy.

Daniell (2004) discussed the strategy process in terms of a "design phase", along with its preceding "diagnosis phase" and its following "implementation phase". Almost nothing was said about this design phase, however, beyond the suggestion that, "The content of this phase sets out the best strategic option to pursue, improves organizational design, clarifies priorities, specifies resource allocation, and identifies priority actions to focus the business on the key levers of performance and value" (Daniell, 2004, p. 146). Once again, no clues regarding how to develop or generate strategy are provided.

It seems, therefore, that when strategists discuss the process of developing or generating strategy it is rarely discussed in any detail. The generative process itself is only referred to briefly and vaguely as the first of three steps in the overall strategy process: (1) creating strategy, (2) evaluating and choosing strategy, and (3) implementing strategy. In Mintzberg's critique of the design school, for example, he said, "On the actual generation of strategies, little is written in this school, besides an emphasis on this being a "creative act," ... Once strategies are created, the next step in the model is to evaluate them and choose the best one. The assumption, in other words - usually implicit - is that several alternative strategies have been produced during the first step, and one is to be selected" (Mintzberg, 1990, p. 175). Strategists, therefore, seem to assume that strategies are somehow created and they focus either on evaluating and choosing strategic options or on change management and strategy implementation.

What we do not see in any of these schools of thought, are considerations of how we actually develop and create strategy. None of these schools of strategic thought provides a coherent theory, methods and tools for how to generate strategy. The design profession (e.g., architects, industrial designers, graphic artists), however, provides a framework as well as many practical and proven methods and tools that are used to generate new ideas and to solve complex problems across a broad range of areas. These design models, methods, tools and techniques can be applied to the generation of organization strategy as well.

\section{Using design to create strategy}

According to the company directors quoted in "Directors on design" (Institute of Directors, 2002), design has been shown to be an integral part of organizational success across a broad range of companies and industries such as web-based services (for people moving home), childcare facilities, point-of-purchase merchandising, automobiles, pottery, law practices, London-based home delivery services, multi-storey car park safety/security, on-line banking and in a microbiology equipment company. While few would argue with the fact that good design makes a difference in many ways, design is nothing new and people have been talking a good deal lately about design and business (cf. Bevan, 2006; Coughlan \& Prokopoff, 2006; Chhatpar, 2007; Fraser, 2007; GolsbySmith, 2007; Martin, 2005a, 2005b, 2005c; Peters, 2005; Vedin 2005). While it is true that design is not new to business and it seems to be getting a good deal of attention lately, when people discuss 
design and business, or design and strategy, they tend to focus on marketing strategy, corporate identity (e.g., branding, image, reputation) and on the design of "things" (i.e., the design of new products and buildings), not on the creation of strategy. For example, Lajocono and Zaccai (2004, p. 75) discussed design in the following way:

"In the literature on design, product development and innovation, the word 'design' refers to many things: a creative art, a phase of product development, a set of functional characteristics, an aesthetic quality, a profession and more. In the lexicon of more and more companies, however, the word has come to denote the totality of activities and competencies that gathers all relevant information and transforms it into a new product or service."

Two other examples of people who seem to think only about the design of "things" are Postrel (2003), who talked about the design of toilet brushes in her popular book entitled The substance of style, and Peters (2005), who discussed the design of hotel beds in his slim volume Design, because, in the first case, well designed toilet brushes add "aesthetic pleasure" and "personal meaning" to life and, in the second case, well designed hotel beds give us a good night's sleep after a long, hard day of doing presentations. While it is undeniable that well designed toilet brushes look and work better and well designed beds are better for our backs, there is much more that design can do for us than help us create new products. Consider the following examples:

- Good community design can increase our health and reduce air pollution. According to the American Planning Association (2006, March): "Poor urban and suburban planning can lead not only to unsightly neighborhoods, but also to obesity and respiratory problems ... Recent studies of King County in Washington State examined a wide variety of impacts that different built environments had on people's health. The researchers found that people who lived in high 'walkability' neighborhoods were generally healthier. Conversely, people who lived in neighborhoods where the layout or location promoted car use over walking or biking were more likely to suffer from obesity and respiratory ailments. According to the report, a $5 \%$ increase in walkability resulted in $32.2 \%$ more minutes per week of physically active travel, as well as lower amounts of air pollution.”

- Steady investment in and commitment to design is rewarded by lasting organizational competitiveness. Evidence of that comes in the results of a Design Council UK (2006) study of the share prices of UK-quoted companies over the last ten years. Their research found that a group of companies recognised as effective users of design outperformed key FTSE indices by 200\%. The 63 companies, grouped into a "Design Portfolio" on the basis of their high level of success in numerous design award schemes, did substantially better than their peers in both the bull and bear markets between 1994 and 2003, the period covered by the study.

- The design of hospital rooms can reduce pain and speed healing. Surgery patients in rooms with lots of natural light took less pain medication, and their drug costs ran $21 \%$ less than for equally ill patients assigned to darker rooms. Those in the brighter rooms also had lower stress levels and said they felt less pain the day after surgery and at discharge (Elias, 2004).

- Design helps an organization differentiate. "Businesses are starting to realise that only one company can be the cheapest in any given market. Design, closely allied to innovation, is the key to standing out and maintaining competitiveness. And that applies whatever the size of the business” (Summers, 2002). According to Formosa and Kroeter (2002) as more and more organizations face “... an increasingly global marketplace, a challenging domestic economic environment, and saturated markets ... [organizations can differentiate] only 
through a unique, 'designerly’ angle, design literacy among corporate management and management recruits is increasingly urgent."

Francis (2002, p. 63) is one of the few authors who have discussed strategy and design beyond simply a consideration of new product development. For example, when he wrote about how designers gain a deep user understanding and empathy for their customers, he suggested that, "Interestingly, they do not study their market with the objectivity of a scientist studying fruit flies but they seek to become part of it. They are emotional, open and excitable - that, as they see it, is their contribution. But it does not look like strategy formulation, does it? Trips to the pool. Hanging out with hip-hoppers. Considering the sexy aspirations of middle-aged women. Studying Zen Buddhism. 'That's not strategy', I hear you say. 'That's fun.' Indeed it is."

Few of us consider strategy development as a chance to be creative, to innovate and to have fun while getting to know our customers intimately and exploring radical new business models and service experiences. We often think of strategy development as technical, focused, serious hard work. When discussing strategy development, we are, for example, much more likely to use metaphors of war (e.g., we pick our battle grounds, defend and attack, devise and deploy plans, do reconnaissance, make a strategic foray and look for counter attacks and aggressive responses from our enemies) than of games, fun and play (e.g., let's toss around an idea, let's play with it for a while and see what happens, let's try it out and see how it feels). Francis (2002, p. 63-64) suggested that:

"A key reason [for this] is that, until recently, strategy was viewed as the apex of corporate achievement and, primarily, a serious, intellectually challenging business. A firm's 'generals' went periodically to a remote county retreat and, like a coven of warlocks, formulated strategic plans, perhaps facilitated by an archpriest from a leading consulting company. Their strategies were formulated and then 'sold' and 'deployed' down through the firm ... Somehow, in rendering strategy a technocratic procedure we demeaned passion and creativity. Moreover, intimacy was lost since strategies were often formulated by those distant from the reality of the market. Top managers found themselves assessing customers' latent needs based on a high-level statistical market analysis. It could happen, for example, that middle-aged men living in sedate mansions in leafy Surrey tried to determine the latent needs of Los Angeles teenagers. This required impossible acts of imagination."

\section{Designing strategy}

In order to use design to create strategy we must understand the design process and how it can be applied to strategy development. In the remainder of this book, therefore, we look more closely "inside" the design process at some of the many design methods, tools and techniques that can help us to develop strategy by design.

Developing strategy by design will do two things for us. First, by employing research techniques that allow us to gain an empathic, deep understanding of our users/customers, and by employing divergent thinking and creativity techniques, we will be able to think about strategy in ways we usually do not. We will be able to develop remarkable new value-creating strategies that add significant value to our organizations and our economies. Second, developing strategy by design will help us evaluate possibilities by taking these ideas and turning them into a series of rapid prototypes. We can then "see it" and "play with it". We can toss around an idea, play with it for a while and see what happens, and just try it out to see how it feels. In this way, strategy formulation becomes less of a linear, technocratic process of data analysis and more of a creative, iterative, emergent and innovative process of creating innovative breakthrough strategy by design. 
While many people focus on the inputs to the design and innovation process, such as expenditure, the need for top management support, the need to gain a deep understanding of the user and provide user support (cf. Bayus, 1995; Fulton Suri, 2005; Coughlan \& Prokopoff, 2006; Jeyaraj, Rottman \& Lacity, 2006), and others measure the outputs of design and innovation such as patents and the number of new products developed (cf. Sero, Guerrero \& Munoz, 2005; Hsu, 2005; Vogel, Cagan \& Boatwright, 2005), few people do more than briefly mention what they consider to be the highest-level steps or phases of the design process ${ }^{3}$. Few seem to consider the design process in any great detail or depth, and virtually no one, in practise or academia, ever discussed its application outside of a narrow range of activities (e.g., new product development or architectural design). In this section, I will discuss the design process and a model of it synthesised from information gathered from working with and interviewing design professionals and from my reading of a large number of relevant publications.

"Serious play", a term coined by Schrage (2000), and the schema of "think, play, do" proposed by Dodgson, Gann and Salter (2005), best capture the spirit of the design process wherein we invent, test, develop and redevelop designs via an iterative process involving the definition of a brief and identification of a problem, research into both the users'/customers' and maker's/organization's requirements, prototyping or modelling partial/potential "solutions" and multiple feedback loops. Blyth and Worthington (2001) discussed the design process and suggested it is an iterative process of proposing, testing, adjusting and reformulating. They also suggested it is not unlike the classic Deming cycle wherein we plan, do something, check the results, adjust our actions, and build our learning into future continuous cycles of planning, doing, checking and adjusting.

Innovation and design are not linear processes wherein we start with an idea, follow the "five steps”, and wind up with a successful product/service or solution. Vedin (2005, p. 294) suggested studies illustrated that the design process had multiple “... generation[s] of increasingly interlinked feedback and feed-forward loops and couplings, often with several impulses generating the impetus for obtaining a dynamically emerging end result". In other words, design is not a linear task; it is an iterative and creative processes. While, in practice, design has a start and an end, once the design process begins, it requires a three-dimensional mode of thinking. The two-dimensional word of linear thinking and problem-solving wherein we logically move from start to finish in a straight-line is not the world of the designer. Designers engage in a non-linear, iterative dance constantly balancing opportunities with restrictions, creativity with anticipated problems, conception with perception (Weick, 2004), and possibilities with budgets and deadlines.

Similarly, Brown (2005, p. 54) stated, "It's a process of enlightened trial and error in which we observe the world around us, identify patterns, generate ideas, get feedback, repeat the process, and keep refining until we are ready." In other words, the design process takes into account the fact that "Nothing is invented and perfected at the same time" (translated from a Latin proverb by Dodgson, Gann, \& Salter, 2005). "Serious play" and multiple iterations, therefore, are integral parts of the design process wherein we are concerned with creating, testing and refining something new, not necessarily perfecting it. Identifying problems, creatively thinking about and generating many potential solutions, and developing, testing and evaluating those solutions is what designers do

\footnotetext{
${ }^{3}$ Examples of some of the many models of the high-level steps/phases in the design process are: analysis, synthesis, evaluation (Lawson, 2006); discover, decide, deliver (Weiss, 2002); think, play, do (Dodgson, Gann, \& Salter, 2005); exploration, refinement, transition (Erickson, 1995); proposing, testing, adjusting, reformulating (Blyth \& Worthington, 2001); knowledge gain, preparation, incubation, stimulation, illumination (Bundy, 2002); observe context, investigate, develop ideas, refine, mock-ups, make, evaluate (Davis, Hawley, McMullan \& Spilka, 1997).
} 
(Summers, 2002), and that is what strategists must do if they want to surprise and delight their customers and reinvent their industries. Prototyping, iterations, feedback and a sense of discovery, creativity and play are consistently stressed in discussions of the design process, and these aspects are sorely lacking in discussions and models of the development of strategy.

In his classic article on logical incrementalism, Quinn (1989) outlined a model of strategy formulation that is very much in line with good design principles. He contrasted the formal systems planning approach with the power-behavioral approach to strategy formulation. In the formal systems planning approach we systematically work through an analysis of our internal situation (e.g., strengths, weaknesses) and our external environments (e.g., opportunities and threats), and we identify gaps between where we are and where we would like to be. We set broad goals and propose plans to help us close these gaps. The power-behavioral approach, on the other hand, focuses more on the "crucial psychological, power, and behavioral relationships in strategy formulation" (Quinn, 1989, p. 46). In this view, it is recognised that organisations have multiple and often competing goals and that people must bargain and negotiate solutions, form coalitions, often make compromises and frequently look as though they are simply "muddling through". Quinn (1989, p. 46) concluded:

"Neither the 'power-behavioral' nor the 'formal systems planning' paradigm adequately characterizes the way successful strategic processes operate ... Effective strategies tend to emerge from a series of 'strategic subsystems,' each of which attacks a specific class of strategic issues (e.g., acquisitions, divestitures, or major reorganizations) in a disciplined way, but which is blended incrementally and opportunistically into a cohesive pattern that becomes the company's strategy ... such incrementalism is not 'muddling'. It is a purposeful, effective, proactive management technique for improving and integrating both the analytical and behavioral aspects of strategy formulation."

In other words, Quinn is suggesting that strategy development is not a technical or analytical task, nor is it solely the result of psychological, power-based behavior relationships. It is an iterative process that continually moves between analysis and intuition, data and fanciful suggestions, formal/logical planning processes and emergent, chaotic informality very much consistent with the design process as practiced by architects, industrial designers, graphic artists, software and systems designers and other design professionals.

\section{A model of strategy by design}

Designing innovative strategies is risky. Incremental improvements to, and extensions of, existing strategies, services and products undoubtedly seem much safer than developing a completely new strategy that challenges the status quo. As with all investments, however, higher risk has the potential to yield higher rewards, and sometimes, while trying something new is uncertain, staying with the status quo is certainly doomed to failure.

When we invest in risky ventures, we try to mitigate the risk by balancing our portfolios of actions or choices and by planning for potential problems. This is one of the reasons why having a design process model is valuable. According to Bruce and Bessant (2002, p. 40), “... the value of a process model is that it provides milestones along the journey where these risks can be assessed.”

Not only do process models provide us with a series of decision-points at which we can assess progress and make decisions about changes in or the continuation of the project, models also can serve as a guide ensuring repeatability of the process, and they provide a checklist of issues helping to ensure that we do not leave out any essential steps of the process, thus enabling us to learn and reducing our risk of failure. 
After looking at several models of the design process (e.g., new product design process models, architectural design process models, and software and systems design process models), the innovation process and the creativity process ${ }^{4}$ and after interviews with several designers from the USA and Australia from a range of design disciplines ${ }^{5}$, it seems most authors and all designers agree that the design process starts with the formulation of a brief (e.g., a goal, wish, problem, specification or challenge/opportunity) that clarifies the parameters of the problem and helps set the limits and requirements for the project. Information must be collected about opportunities in the market and about the company itself. Critical analysis is required of markets, the company and the general environment within which it operates. Activities in this early stage include such things as broad exploration, problem investigation, problem definition, product specification and the generation of a design brief.

The next step in the process is to conduct various forms of research to gain insights into the users/consumers, the competition, the maker/organization, the market, relevant government policy, etc. It is critical that both user issues (i.e., design issues related to the way the final designed outcome interacts with users of it), and maker issues (i.e., design issues related to realising the outcome being designed - to do with production techniques, tools, materials as well as broader organization and industry analysis) must be considered (Boyle, 2004; Holt, 1990; Kimbell, Stables \& Green, 1996). Once we know what the brief is, and we have gained some insights into the users/consumers, the organization and it's external environment, we use this information to help start the creative process of concept generation.

This creative, divergent thinking process is followed by the quick development of a rough plan, model or prototype. The divergent, expanding, creative impetus must be counter-balanced by a more convergent, inward and practical thrust. This "phase is indispensable to any creative project ... we must call upon our own judgement and the judgement of others to verify - not only to assay our final findings, but also at intermediate stages, for such purposes as to focus objectives, and to call out hypotheses" (Osborn, 1953, p. 180). In other words, we must continually check back with the brief, evaluate the solution, adjust our efforts and continue the process. This is a critical point as it introduces accountability and safeguards into the process.

This convergent aspect allows the start of an iterative process of evolution, refinement and redevelopment wherein we prototype/model, evaluate and judge the resultant ideas/models, refine solutions, check if they work and address the brief or solve the problem, creatively generate more ideas and/or modifications, and re-model until we are satisfied or run out of time and we deliver the output. According to many authors and designers, this iterative process of creative, divergent generation and convergent refinement is a key part of designing. Frequent iterations of designs, extensive testing of those designs, and short time intervals between successive milestones have been shown to improve design process performance, especially under conditions of uncertainty (Brown \& Eisenhardt, 1995). Finally, we move to the stage where we make a decision and deliver or transfer the project output. The overall process as discussed above can be illustrated as in Figure 1. In the following chapters we will discuss each phase and element in the model in more detail.

\footnotetext{
${ }^{4}$ I studied models from Bevan (2006), Blyth \& Worthington (2001); Boyle (2004); Bundy (2002), Cross (2000), Davis et al. (1997), Erickson (1995), Kimbell (1982), Lawson (2004, 2006), Nussbaum, (2004), Oakley (1984, 1990), Osborn (1953), Osborn-Parnes Creative Problem Solving Cycle from Hughes (2003), Rubinstein \& Hersh (1984); Vogel, Cagan \& Boatwright (2005) and Weiss (2002).

${ }^{5}$ Architectural design, Industrial design, Graphic design and Interior design.
} 
Figure 1. A model of the strategy by design process.

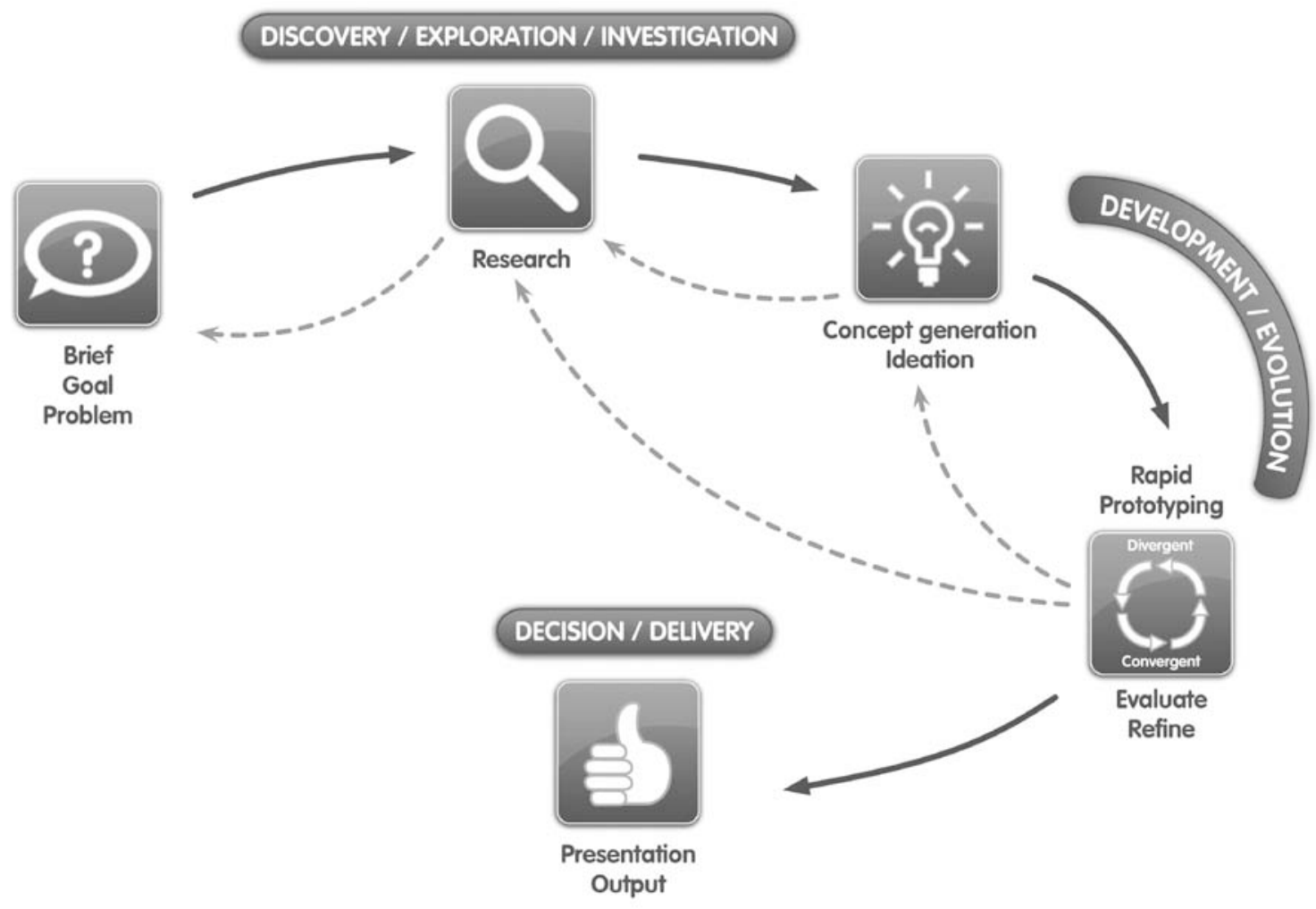




\section{References}

American Planning Association (2006, March). Healthier Neighborhoods. www.planning.org.

Bayus, B. (1995). Optimal dynamic policies for product and process innovation. Journal of Operations Management, vol. 12, \# 3,4, 173-185.

Bevan, G. (2006). The industrial design process. In Industrial Design Showcase (Edt. James Tuckerman), Australian Anthill, February-March.

Blyth, A. \& Worthington, J. (2001). Managing the brief for better design. Taylor \& Francis: London.

Boyle, G. (2004). Design project management. Ashgate: London.

Brown, T. (2005). Strategy by design. Fast company, June, \# 95, 52-54.

Brown, S. \& Eisenhardt, K. (1995). Product development: Past research, present findings, and future directions. The Academy of Management Review, vol. 20, \# 2, 343-378.

Bruce, M. \& Bessant, J. (2002). Design in business. Harlow: London.

Bundy, W. (2002). Innovation, creativity, and discovery in modern organisations. Quorum: Westport, Connecticut.

Chhatpar, R. (2007). Innovate faster by melding design and strategy. Harvard Business Review, vol. 85, \# 9, 30-32.

Coughlan, P. \& Prokopoff, I (2006). Managing change, by design. Rotman, Winter, 20-23.

Cross, N. (2000). Engineering design methods. Wiley: Chichester.

Daniell, M. (2004). Strategy: A step-by-step approach to the development and presentation of world class business strategy. Palgrave McMillan: Hampshire, UK.

Davis, M., Hawley, P., McMullan, B., \& Spilka, G. (1997). Design as a catalyst for learning. Alexandria, Virginia: Association for Supervision and Curriculum Development.

Deluzio, M. \& Hawkey, B. (2006). Strategy deployment: Effective alignment of LEAN to drive profitability growth. Cost Management, vol. 20, \# 2, 30-39.

Design Council UK (2006, February 26) www.design-council.org.uk.

Dodgson, M., Gann, D., \& Salter, A. (2005). Think, play, do. Oxford University Press: Oxford, UK.

Donaldson, L. (1985). In defense of organizational theory. Cambridge University: Cambridge.

Donaldson, L. (1991). The contingency theory of organizations. Sage: CA.

Elias, M. (2004). Sunlight reduces need for pain medication. USA Today, 3 March. 
Ellingson, M. (1933). Education and research at a mechanics institute: III. Activity analysis. Personnel Journal, vol. 12, 12-15.

Erickson, T. (1995). Notes on design practice: Stories and prototypes as catalysts for communication (37-58). In J. Carroll (Edt), Scenario-based design: Envisioning work and technology in system development. Wiley: New York.

Farnham, D. \& Horton, S. (2003). Organisational change and staff participation and involvement in Britain's public services. The International Journal of Public Sector Management, vol. 16, \# 6, 434448.

Formosa, K. \& Kroeter, S. (2002). Toward design literacy in American management: A strategy for MBA programs. Design Management Journal, Vol. 13, \# 3, 46-54.

Francis, D. (2002). Strategy and design (61-75). In M. Bruce and J. Bessant (Edts.), Design in Business. Harlow: London.

Fraser, H. (2007). The practice of breakthrough strategies by design. Journal of Business Strategy, vol. 28, \# 4, 66-74.

Fulton Suri, J. (2005). Thoughtless acts? Observations on intuitive design. Chronicle: San Francisco.

Godin, S. (2001). Purple cow. Penguin: London, UK.

Godin, S. (2005). The big moo: Stop trying to be perfect and start being remarkable. Penguin: New York.

Goldsby-Smith, T. (2007). The second road of thought: how design offers strategy a new toolkit. Journal of Business Strategy, vol. 28, \# 4, 22-29.

Hambrick, D. \& Fredrickson, J. (2005). Are you sure you have a strategy? The Academy of the Management Executive, vol.19, \# 4, sp 51.

Hamel, G. (1998). Strategy emergence. Executive Excellence, vol. 15, \# 12, 3-4.

Holt, K. (1990). The nature of the design process (195-205). In M. Oakley (Etd.), Design management: A handbook of issues and methods. Blackwell: Cambridge, MA.

Hsu, K. (2005). Using balanced scorecard and fuzzy data envelopment analysis for multinational R \& D project performance assessment. Journal of American Academy of Business, vol. 7, \# 1, 189196.

Hughes, G. (2003). Add creativity to your decision processes. The Journal for Quality \& Participation, Summer, 5-13.

Institute of Directors (2002). Directors on design. Director Publications: London, UK.

Jeyaraj, A. Rottman, J. \& Lacity, M. (2006). A review of the predictors, linkages, and biases in IT innovation adoption research. Journal of Information Technology, vol. 21, 1-23. 
Jirotka, M. \& Luff, P. (2006). Supporting requirements with video-based analysis. IEEE Software, May/June, 42-44.

Johnson, D., Donohue, W., Atkin, C. \& Johnson, S. (2001). Communication, involvement,

Kimbell, R. (1982). Design education. Routledge: London, UK.

Kimbell, R., Stables, K. \& Green, R. (1996). Understanding practice in design and technology. Open University Press: Buckingham, UK.

Lajocono, G. \& Zaccai, G. (2004). The evolution of the design-inspired enterprise. MIT Sloan Management Review, Spring, 75-79.

Lawson, B. (2006). How designers think: The design process demystified (fourth edition). Elsevier: Oxford, UK.

Lawson, B. (2004). What designers know. Elsevier: Oxford, UK.

Martin, R. (2005a). Creativity That Goes Deep. BusinessWeek Online August 3.

Martin, R. (2005b). Why decisions need design. BusinessWeek Online, August 30, 2005.

Martin, R. (2005c). Reliability vs. Validity. BusinessWeek Online September 29, 2005.

Mintzberg, H. (1990). The design school: Reconsidering the basic premises of strategic management. Strategic Management Journal, vol. 11, \# 3, 171-195.

Mintzberg, H., Ahlstrand, B. \& Lampel, J. (1998). Strategy Safari. Free Press: New York.

Mintzberg, H. \& Lampel, J. (1999). Reflecting on the strategy process. Sloan Management Review, vol. 40, \# 3, 21-30.

Nussbaum, B. (2004). The power of design. BusinessWeek Online (www.businessweek.com), May 17.

Oakley, M. (1984). Managing product design. Weidenfeld and Nicolson: London.

Oakley, M. (1990). Design and design management (1-14). In M. Oakley (Etd.), Design management: A handbook of issues and methods. Blackwell: Cambridge, MA.

Osborn, A. (1953). Applied imagination. Scribner: New York.

Peters, T. (2005). Design. DK: New York.

Porter, M. (1980). Competitive strategy. Free Press: New York.

Porter, M. (1996). What is strategy? Harvard Business Review, vol. 74, \# 6, 61-78.

Postrel, V. (2003). The substance of style. Harper: New York.

Quinn, J. B. (1989). Strategic change: "Logical incrementalism". Sloan Management Review, Summer, 45-60. 
Rubinstein, R. \& Hersh, H. (1984). The human factor. Digital Press: U.S.A.

Schrage, M. (2000). Serious play. Harvard Business School Press: Boston, MA.

Sero, M., Guerrero, D. \& Munoz, R. (2005). Generating technological knowledge in Spanish universities: An exploration of patent data. Innovation: Management, Policy \& Practice, vol 7, \# 4, 357-372.

Summers, A. (2002). Immaculate conceptions. Financial Management; June, sp 20

Vedin, B. (2005). Future innovation through design (293-303). In C. Wagner (Etd.), Foresight, innovation, and strategy. World Future Society: Bethesda, Maryland.

Vogel, C., Cagan, J., \& Boatwright, P. (2005). The design of things to come. Pearson Education: New Jersey, USA.

Wagner, E. \& Hansen, E. (2004). A method identifying and assessing key customer group needs. Industrial marketing Management, Vol. 33, 643-655.

Weick, C. (2004). Rethinking organizational design (36-53). In R. Boland \& F. Collopy (Edts.), Managing as designing, Stanford: CA.

Weiss, L. (2002). Developing tangible strategies. Design Management Journal, vol. 13, \# 1, 33-38. 